\title{
Effects of Fire Retardants on the Fire, Thermal and Mechanical Properties of Wood Plastic Composites Using Recycled Fibers
}

\author{
*Ertuğrul ALTUNTAŞ ${ }^{1 *}$, Eyyup KARAOĞUL ${ }^{2}$, M. Hakkı ALMA $^{1}$ \\ 1*Kahramanmaras Sutcu Imam University, Faculty of Forestry, 46100 Kahramanmaras/TURKEY \\ ${ }^{2}$ Harran University, Faculty of Engineering, 63000 Sanliurfa/TURKEY \\ *Corresponding author: ealtuntas@ksu.edu.tr
}

Received Date: 18.07.2017

Accepted Date: 24.08 .2017

\section{Abstract}

Aim of study: This study compared the effects of boron-based fire retardants and synergistic influential compounds used in medium-density fiberboard waste (MDFw) filled high-density polyethylene (HDPE) composites.

Area of study: To improve the use of boron based and fire retardant materials in wood plastic composite.

Material and Methods: Fiber waste, HDPE and boron- based compounds were used to produce wood plastic composites. Mechanical thermal and fire properties of the produced composites were investigated.

Main results: When fire retardants were used in composites, the mechanical properties of composite with MAPE increased slightly, also the modulus of elasticity of composites increased considerably. Boron-based fire retardants and other synergistic influential compounds decreased the burning rate and limiting oxygen index (LOI) properties of the composites.

Research highlights: The use of the zinc borate in the MDFw-based wood plastic composite had the best results on the mechanical and fire-retardant properties.

Keywords: Fire Retardant, thermal properties, zinc borate, and synergic effect

\section{Geri Dönüşüm Liflerinin Kullanıldığı Odun Plastik Kompozitlerin Yangın, Termal ve Mekanik Özellikleri Üzerine Yangın Geciktiricilerin Etkileri}

Özet

Çalışmanın amacı: Bu çalışmada lifsel atıklar ile üretilen odun plastik kompozitlerde bor esaslı (Borik asit, boraks ve çinko borat) yangın geciktiriciler ve sinerjik etkili bileşiklerin (antimon trioksit, amonyum fosfat ve magnezyum hidroksit) etkileri araştırıldı. Bu çalışmada, kompozitlerin üretilmesinde orta yoğunluklu lif levhaların (MDF) atıkları ve yüksek yoğunluklu polietilen (YYPE) plastik hammadde kullanılmıştır.

Çalışma alanı: odun plastik kompozitlerin yangına karşı direncinin geliştirilmesi.

Materyal ve Yöntem: Odun plastik kompozitlerin üretilmesi için lifsel atıklar, HDPE ve bor esaslı bileşikler kullanıldı. Kompozitlerin üretilmesi için çift vida ekstruder kullanıldı.Üretilen kompozitlerin mekanik termal ve yangın özellikleri araştırıldı.

Sonuçlar: Bu amaçla farklı bor esaslı maddeler, sinerjik etkili bileşikler ve maleik anhidrit muamele edilmiş polietilen (MAPE) ile üretilen kompozitlerin yangın, termal ve mekanik özelliklerine olan etkisi incelendi. Elde edilen sonuçlara göre yangın geciktiricilerin ve MAPE'nin birlikte kullanıldı̆̆ kompozitlerin eğilme ve çekme dirençlerinin yanı sıra kompozitlerin elastikiyet modülleri belirgin şekilde arttığ 1 anlaşılmıştır. Bor esaslı yanma geciktiriciler ve diğer sinerjik etkili bileşikler, kompozitlerin yatay yanma hızını düşürdüğü ve oksijen endeksi (LOI) özelliklerini geliştirdiği anlaşılmıştır.

Araştırma vurguları: Çinko boratın MDF atıkları ile hazırlanmış odun plastik kompozitlerde kullanılması, mekanik ve yangın geciktirici özellikleri açısından en iyi sonuçları verdiği anlaşılmıştır.

Anahtar Kelimeler: Yangın geciktirici, termal özellikler, çinko borat ve sinerjik etki 


\section{Introduction}

A large quantity of lignocellulosic wastes occurs from the different human activities. The Lignocellulosic materials and wastes can be obtained from industrial factories as well as naturel resources. The fiberboard industry has grown very rapidly since the second half of the twentieth century. At the same time, the use of the medium density fiberboard has increased considerably. A large amount of waste has been generated during the production and processing of medium density fiberboard. The medium density fiberboard wastes are either burnt or land filled. This wastes cause various environmental problems like air pollution, emission containing the formaldehyde or occupation of useful land. MDFw can be used in production of the wood plastic composites (Karade, 2010).

The wood plastic composites (WPCs) have been used recently in the different construction and the building applications, such as decking, siding, benches, auto parts, and fencing. The lignocellulosic filling used in the WPCs is easily available and less expensive than other fillers. WPCs have the many advantages, such as lower resin costs, improved stiffness, and dimensional stability. Lignocellulose materials such as sawdust, annual crops, forest waste, and recycled fibers have been used in the production of WPCs.

Efforts to expand the use of wood-based products in institutional and commercial structures may require that they be treated with flame retardant compounds (Levan, 1984). Boron compounds such as sodium tetraborate, boric acid, and zinc borate, help to prevent the spread of fire in wood products, and they have been used as fire retardants in the production of plastics since the late 1970s (Chai, Liu, and Xing, 2012; G. F. $\mathrm{Wu}$ and $\mathrm{Xu}, 2014)$. Boron compounds also have been used to protect wood from fungi and insects, such as termites (Ayrilmis, 2013). In addition, boron compounds have been used to reduce the thermal degradation of composite materials (Z. P. Wu, Hu, and Shu, 2010). Many fire-retardant compounds, such as ammonium phosphate, diammonium phosphate, magnesium hydroxide, and aluminum trihydrate are available for polymer composites (Chiang and $\mathrm{Hu}, 2001$; G. F. Wu and $\mathrm{Xu}, 2014)$.

The study was conducted in two stages. In the first stage, we determined which boron compound provided the best resistance to fire in WPCs. In the second step, the synergistic effects between the best boron compound and various fire retardants were examined. We also examined the effect of MAPE in the composite with the best boron compound. We conducted the horizontal burning rate test, the limiting oxygen index (LOI) test, and thermal gravimetric analysis (TGA) of the composite samples. In addition, we determined the mechanical properties of the composites including their tensile and flexural strength, modulus and impact strength.

\section{Material and Method \\ Materials}

The MDF particles were obtained from the Kastamonu Entegre Co. (Adana, Turkey). These fiber particles are separated into 60mesh fibers using screens, and the fibers are dried at $103{ }^{\circ} \mathrm{C}$ before the manufacturing process begins. High-density polyethylene (HDPE, density: $0.965 \mathrm{~g} / \mathrm{cm} 3$ ) and paraffin wax, which was used as a lubricant during extrusion, were provided by the Petkim Petrochemical Co. (Izmir, Turkey). MAPE was supplied by Clariant International Co. (Shanghai, China) and used as a coupling agent in some composite boards. Boric acid $\left(\mathrm{H}_{3} \mathrm{BO}_{3}\right)$, sodium and tetraborate $\left(\mathrm{Na}_{2} \cdot \mathrm{B}_{4} \cdot \mathrm{O}_{7} \cdot 10 \mathrm{H}_{2} \mathrm{O}\right)$, were obtained from Eti Mine Works Factory (Balikesir, Turkey). Zinc borate $\left(\mathrm{ZnO} \cdot 2 \mathrm{~B}_{2} \mathrm{O}_{3} \cdot 3.5 \mathrm{H}_{2} \mathrm{O}\right)$ was obtained from the Aromos Chemistry Co. (Izmir, Turkey).Antimony trioxide $\left(\mathrm{Sb}_{2} \mathrm{O}_{3}\right)$, ammonium phosphate $\left.\left(\mathrm{NH}_{4}\right) 3 \mathrm{PO}_{4}\right)$, and magnesium hydroxide $\left(\mathrm{Mg}(\mathrm{OH})_{2}\right)$ were obtained from Tekkim Chemistry Co. (Istanbul, Turkey).

\section{Methods}

Contents of composite samples were prepared according to Table 1 . The prepared materials were mixed with a high-speed mixer (speed range of 5 to $1000 \mathrm{rev} / \mathrm{min}$ for $5 \mathrm{~min}$ ) before the extrusion process. A twinscrew extruder was used to produce the composites; the temperatures of the 
extruder's barrel were set at $165,170,175$, 180 , and $185{ }^{\circ} \mathrm{C}$ for the warm regions of extruder $1,2,3,4$, and 5 , respectively. The temperature of the die zone of the extruder averaged $195{ }^{\circ} \mathrm{C}$. The extruded composite samples were pelletized. The pellets were dried at $103{ }^{\circ} \mathrm{C}$ to the moisture content of 1 to $2 \%$ before the hot press. The pellets were pressed for $10 \mathrm{~min}$ at a pressure of $100 \mathrm{bar}$ and a temperature of $180{ }^{\circ} \mathrm{C}$. The obtained composite boards were conditioned according to ASTM D-618 standards.

\section{Horizontal Burning Rate and Limiting Oxygen Index (LOI) Tests}

The flame retardancy of the WPCs was determined by horizontal burning tests according to ASTM D-635. Specimens (5 (t) $\times 13(\mathrm{w}) \times 125(\mathrm{~mm})$ were conditioned in an controlled room at relative humidity of $50 \pm$
$5 \%$ and temperature of $23 \pm 2{ }^{\circ} \mathrm{C}$ for $48 \mathrm{~h}$. Six specimens were tested for each group of samples. The limiting oxygen index test was performed according to ASTM D-2863-10 using a Dynisco limiting oxygen index chamber. The normal oxygen concentration required to support combustion was recorded as a percentage for all samples

\section{Thermo Gravimetric Analysis (TGA) \\ Test}

Powdered test samples were used for the thermogravimetric analysis (TGA). The analyses were performed in a Shimadzu TGA-50 thermal analyzer (Kahramanmaras Sutcu Imam University, Forest Faculty, Kahramanmaras, Turkey) at a heating rate of $10{ }^{\circ} \mathrm{C} / \mathrm{min}$ up to $800{ }^{\circ} \mathrm{C}$ under a nitrogen flow of $\quad 100 \quad \mathrm{~mL} / \mathrm{min}$.

Table 1. Weight Percentages of Composite Samples.

\begin{tabular}{|c|c|c|c|c|c|c|c|c|c|c|}
\hline \multirow{2}{*}{$\begin{array}{c}\text { Sample } \\
\text { Code }\end{array}$} & \multicolumn{10}{|c|}{ Composition Based on Weight (\%) } \\
\hline & $\begin{array}{c}\text { MDF } \\
\text { Wastes }\end{array}$ & HDPE & IAPE & $\begin{array}{c}\text { Boric } \\
\text { Acid }\end{array}$ & $\begin{array}{c}\text { Sodium } \\
\text { Tetraborate }\end{array}$ & $\begin{array}{c}\text { Zinc } \\
\text { Borate }\end{array}$ & $\begin{array}{l}\text { Antimony } \\
\text { Trioxide }\end{array}$ & $\begin{array}{l}\text { Ammonium } \\
\text { Phosphate }\end{array}$ & $\begin{array}{l}\text { Magnesium } \\
\text { Hydroxide }\end{array}$ & $\begin{array}{c}\text { PE } \\
\text { wax }\end{array}$ \\
\hline Control & 59 & 40 & & & & & & & & 1 \\
\hline H-MA & 59 & 37 & 3 & & & & & & & 1 \\
\hline H-BA & 47 & 40 & & 12 & & & & & & 1 \\
\hline H-BX & 47 & 40 & & & 12 & & & & & 1 \\
\hline $\mathrm{H}-\mathrm{CB}$ & 47 & 40 & & & & 12 & & & & 1 \\
\hline $\mathrm{H}-\mathrm{MCB}$ & 44 & 40 & 3 & & & 12 & & & & 1 \\
\hline $\mathrm{H}-\mathrm{ACB}$ & 47 & 40 & & & & 6 & 6 & & & 1 \\
\hline $\mathrm{H}-\mathrm{CBA}$ & 47 & 40 & & & & 6 & & 6 & & 1 \\
\hline $\mathrm{H}-\mathrm{CBF}$ & 47 & 40 & & & & 6 & & & 6 & 1 \\
\hline
\end{tabular}

\section{Mechanical Tests}

Tensile strength (TS) and tensile modulus (TM) was determined according to ASTM D638 with a crosshead speed of $5 \mathrm{~mm} / \mathrm{min}$ and a load cell of $0.1 \mathrm{kN}$. Flexural strength (FS) and flexural modulus (FM) was determined according to ASTM D-790 with a crosshead speed of $2 \mathrm{~mm} / \mathrm{min}$ using a Universal Testing Machine (UTM) (Zwick/Roel, model Z010, Germany) at room temperature. The impact strength (IS) test was performed at room temperature with a pendulum impact tester (Zwick, HIT5.5P, Germany) according to ASTM D-256. Notches were made using a notching cutter (Ray-Ran Test Equipment, Ltd., Polytest; UK). Eight samples were tested to determine their tensile, flexural, and impact strengths.

\section{Results and Discussion \\ Flame Retardancy and Limiting Oxygen Index Performance}

Table 2 shows the burning rates of the composites, which ranged from 7 to 28 $\mathrm{mm} / \mathrm{min}$. The composite with zinc borate has the lowest burning rate. It is understood that addition of fire retardants increases the heat resistance of composites according to the table 2 . Especially the addition of zinc borate in composite reduced by $380 \%$ the burning rate when compared to the control example. The burning rate of the composite including together zinc borate and MAPE is higher 
than that of the composites including only zinc borate. The effects of MAPE in WPCs were examined in a previous study (G. F. Wu and $\mathrm{Xu}, 2014)$. The boron compounds absorb the heat released by fire. This situation may release with the heat capacity rather than the polymer or lignocellulosic. When the polymer and lignocellulosic material are exposed to temperature, boron compounds generally reduce the flammability by forming a coating layer (Cavdar, Mengeloglu, and Karakus, 2015; Kurt, Mengeloglu, and Meric, 2012). Composites mixing other fire retardants were compared for their synergistic effects. The composite including together zinc borate and antimony trioxide had the best synergistic effect. Some of the inorganic compounds have synergetic effect for wood composites. The Antimony trioxide has an excellent synergistic effect in using with boron compounds (Klyosov, 2007).

Table 2. Burning rate and LOI results of composites

\begin{tabular}{ccc}
\hline $\begin{array}{c}\text { Sample } \\
\text { Code }\end{array}$ & $\begin{array}{c}\text { Burning Rate } \\
(\mathbf{m m} / \mathbf{m i n})\end{array}$ & $\begin{array}{c}\text { LOI } \\
\left(\boldsymbol{\%} \mathbf{O}_{\mathbf{2}}\right)\end{array}$ \\
\hline Control & $27.74(1.20)^{*}$ & $20 \pm 0.2$ \\
\hline H-MA & $28.04(0.96)$ & $20 \pm 0.2$ \\
\hline H-BA & $14.18(1.08)$ & $21 \pm 0.2$ \\
\hline H-BX & $8.97(1.25)$ & $22 \pm 0.2$ \\
\hline H-CB & $7.33(0.44)$ & $22 \pm 0.2$ \\
\hline H-MCB & $12.26(1.23)$ & $21 \pm 0.2$ \\
\hline H-ACB & $10.25(0.33)$ & $21 \pm 0.2$ \\
\hline H-CBA & $11.98(1.22)$ & $21 \pm 0.2$ \\
\hline H-CBF & $12.18(1.50)$ & $21 \pm 0.2$ \\
\hline $\begin{array}{l}\text { Note: Standard deviation } \\
\text { parentheses }\end{array}$ & shown in
\end{tabular}

Kurt and Mengeloglu (2012) reported the WPCs with boron compounds and ammonium polyphosphate were investigated for the burning rate. They also showed that composites had a synergistic effects and the composite containing altogether boric acid, borax and ammonium polyphosphate reduced by $50 \%$ the burning rate.

Ayrilmis (2012) reported that the fire performance of WPCs with zinc borate was investigated. They also showed that zinc borate enhanced the fire performance of composite. Many studies have shown that the using together antimony trioxide and zinc borate is more effective in high temperature polymer applications (Shen, Kochesfahani, and Jouffret, 2008).

The LOI results of the composite materials are shown in Table 2 . The highest values were obtained from the composites with zinc borate and sodium borate. The addition of fire retardants slightly increased the LOI results of composites. Although the LOI results of the composites not significantly increased, the residue amount increased. The addition of 3\% MAPE into the composite accelerated the rate of heat transfer. Therefore the oxygen index of composite decreased (Cavdar, Mengeloglu, Karakus, and Tomak, 2014).

\section{Thermal Properties}

The TGA results of composite samples were showed in Table 3. The TGA results indicated that the degradation of all samples took place in two main stages. It was concluded that the lignocellulose material deteriorated in the first degradation stage and that the plastic material deteriorated in the second degradation stage (Mengeloglu and Kabakci, 2008).

The TGA curves are given in Figure 1. All composites with fire-retardant agents had better thermal characteristics than the control group. Moreover, the thermal resistance of composite only added 3\% MAPE was less than the control. This result may have been due to the crosslinks of the MAPE between the polymer and fire retardant, which had a positive influence on the thermal conductivity of the composite. This thermal conductivity may increase heat dissipation. Similar results were obtained from that MAPE added the composites for the flame retardancy tests (Ayrilmis, 2013). 

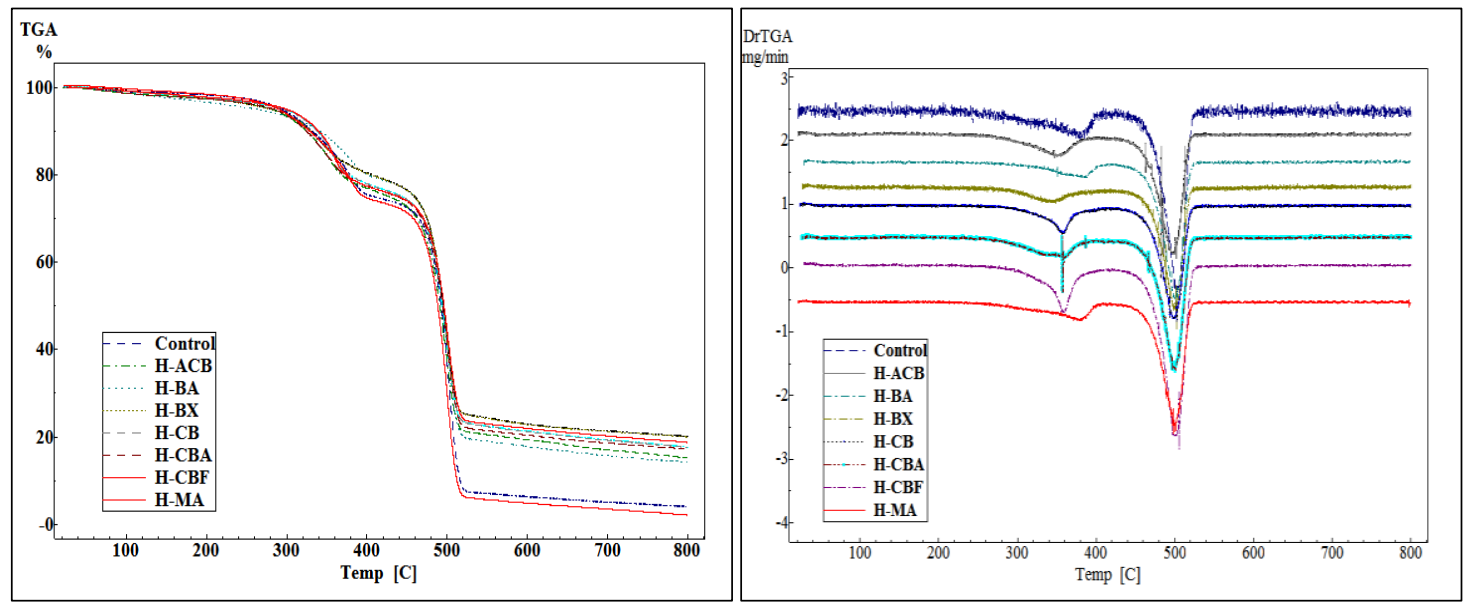

Figure 1. TGA and dTGA curves of composite samples

Table 3. TGA results of the composite samples.

\begin{tabular}{|c|c|c|c|c|c|c|}
\hline \multirow{2}{*}{ Samples } & \multirow{2}{*}{$\begin{array}{c}\text { First } \\
\text { Degradation } \\
\text { Temperature } \\
\text { Range }\left({ }^{\circ} \mathrm{C}\right)\end{array}$} & \multirow{2}{*}{$\begin{array}{l}\text { First } \\
\text { Peak } \\
\left({ }^{\circ} \mathrm{C}\right)\end{array}$} & \multirow{2}{*}{$\begin{array}{c}\text { Second } \\
\text { Degradation } \\
\text { Temperature } \\
\text { Range }\left({ }^{\circ} \mathrm{C}\right)\end{array}$} & \multirow{2}{*}{$\begin{array}{l}\text { Second } \\
\text { Peak } \\
\left({ }^{\circ} \mathrm{C}\right)\end{array}$} & \multicolumn{2}{|c|}{$\%$ Residue } \\
\hline & & & & & $500^{\circ} \mathrm{C}$ & $800^{\circ} \mathrm{C}$ \\
\hline Control & $254-364$ & 332 & $418-493$ & 499 & 37.5 & 4.2 \\
\hline H-MA & $240-365$ & 339 & $413-490$ & 498 & 35.2 & 2.6 \\
\hline H-BA & $292-413$ & 372 & $420-507$ & 501 & 42 & 14.1 \\
\hline H-BX & $270-395$ & 342 & $430-505$ & 500 & 43.2 & 20 \\
\hline $\mathrm{H}-\mathrm{CB}$ & $287-422$ & 357 & $432-506$ & 502 & 42.5 & 17.5 \\
\hline H-MCB & 264-395 & 351 & $428-506$ & 500 & 41.3 & 16 \\
\hline $\mathrm{H}-\mathrm{ACB}$ & $269-395$ & 351 & $428-506$ & 502 & 38.3 & 15.3 \\
\hline $\mathrm{H}-\mathrm{CBA}$ & $260-391$ & 357 & $435-507$ & 501 & 41.2 & 17.3 \\
\hline $\mathrm{H}-\mathrm{CBF}$ & $277-402$ & 360 & $432-511$ & 505 & 44.2 & 18.7 \\
\hline
\end{tabular}

The residual amounts of the composites samples were increased when the fire retardants in composite was added. Among the boron compounds, zinc borate showed the best thermal performance by increasing the initial degradation temperature by about $40{ }^{\circ} \mathrm{C}$ compared with the control. Zinc borate was followed by boric acid and sodium tetraborate, with initial increases in the degradation temperature of about 28 and 15 ${ }^{\circ} \mathrm{C}$, respectively. Zinc borate had good fireretardant and smoke suppressant properties. During the burning of the material that contained zinc borate a glass-like layer was created due to the decomposition of the zinc borate, and this layer protected the material by preventing the oxidation of the polymeric structures (Nikolaeva and Karki, 2016). However, the addition of MAPE to the formulation of $\mathrm{H}-\mathrm{ZB}$ had a negative effect on the thermal resistance of the composite. Zinc borate showed the best synergistic thermal performance in combination with magnesium hydroxide. The synergy effect increased the initial degradation temperature by about 35 ${ }^{\circ} \mathrm{C}$ compared with the control sample. However, this value was slightly lower than the value for the sample in which only zinc borate was used as a fire retardant. The magnesium hydroxide clearly demonstrated a better synergistic effect with zinc borate than antimony trioxide, and ammonium phosphate. Zinc borate produced the best synergetic effect in combination with aluminum and magnesium hydroxides. It was reported that the combined use of different fire retardants in composites produced a synergistic effect (Haurie et al., 2007). 
Table 4. Mechanical tests results of composites

\begin{tabular}{ccccccccccc}
\hline ID & \multicolumn{1}{c}{ FS $(\mathbf{M P a})$} & \multicolumn{2}{c}{ FM $(\mathbf{M P a})$} & \multicolumn{2}{c}{ TS $(\mathbf{M P a})$} & \multicolumn{2}{c}{ TM $(\mathbf{M P a})$} & \multicolumn{2}{c}{ IS $\left(\mathbf{J} / \mathbf{m}^{\mathbf{2}}\right)$} \\
\hline Control & $35.8^{*}$ & $1.77^{* *}$ & 1949.2 & 236.43 & 14.9 & 0.41 & 701.2 & 32.44 & 38.7 & 2.80 \\
\hline H-MA & 42.1 & 1.82 & 1843.5 & 148.23 & 20.3 & 0.54 & 692.6 & 23.21 & 39.8 & 3.70 \\
\hline H-BA & 27.7 & 1.52 & 2112.1 & 87.18 & 11.6 & 0.38 & 678.9 & 33.01 & 28.5 & 2.0 \\
\hline H-BX & 28.5 & 1.69 & 2419.1 & 129.68 & 12.8 & 0.93 & 805.5 & 40.11 & 29.2 & 1.62 \\
\hline H-CB & 30.8 & 1.28 & 2438.7 & 133.26 & 13.1 & 0.3 & 733.0 & 70.39 & 25.1 & 1.24 \\
\hline H-MCB & 32.8 & 1.98 & 2455.8 & 271.88 & 16.0 & 0.69 & 824.5 & 48.90 & 24.1 & 1.17 \\
\hline H-ACB & 33.5 & 1.12 & 2534.2 & 97.26 & 12.9 & 0.36 & 802.7 & 19.32 & 25.8 & 1.37 \\
\hline H-CBA & 30.7 & 1.04 & 2488.3 & 154.26 & 12.9 & 0.39 & 751.1 & 40.72 & 27.7 & 1.26 \\
\hline H-CBF & 30.2 & 1.56 & 2412.8 & 182.94 & 12.6 & 0.32 & 810.4 & 29.51 & 24.7 & 1.66 \\
\hline
\end{tabular}

FS: Flexural strength; FM: Flexural modulus; TS: Tensile Strength; TM: Tensile modulus; IS:

Impact strength; *Average value **Standard deviation

\section{Mechanical Properties}

Figure 2 shows the FS of the samples prepared according to Table 4 . The FS of the samples prepared by adding different boron compounds was compared. The best flexural strength was $\mathrm{H}-\mathrm{ACB}$, which was added to zinc borate only. Compared with the control group, the FS of H-CB decreased by $14 \%$, but the flexural modulus (FM) increased by
$25 \%$. Flame retardants may reduce the TS of filled and unfilled thermoplastics (Chiu and Wang 1998; Horn 2000; Sain et al. 2004). The effect of the coupling agent in WPCs has also been investigated (Kurt and Mengeloglu, 2011; Leu, Yang, Lo, and Yang, 2012; Matuana, Balatinecz, Sodhi, and Park, 2001; G. F. Wu and $\mathrm{Xu}, 2014)$.

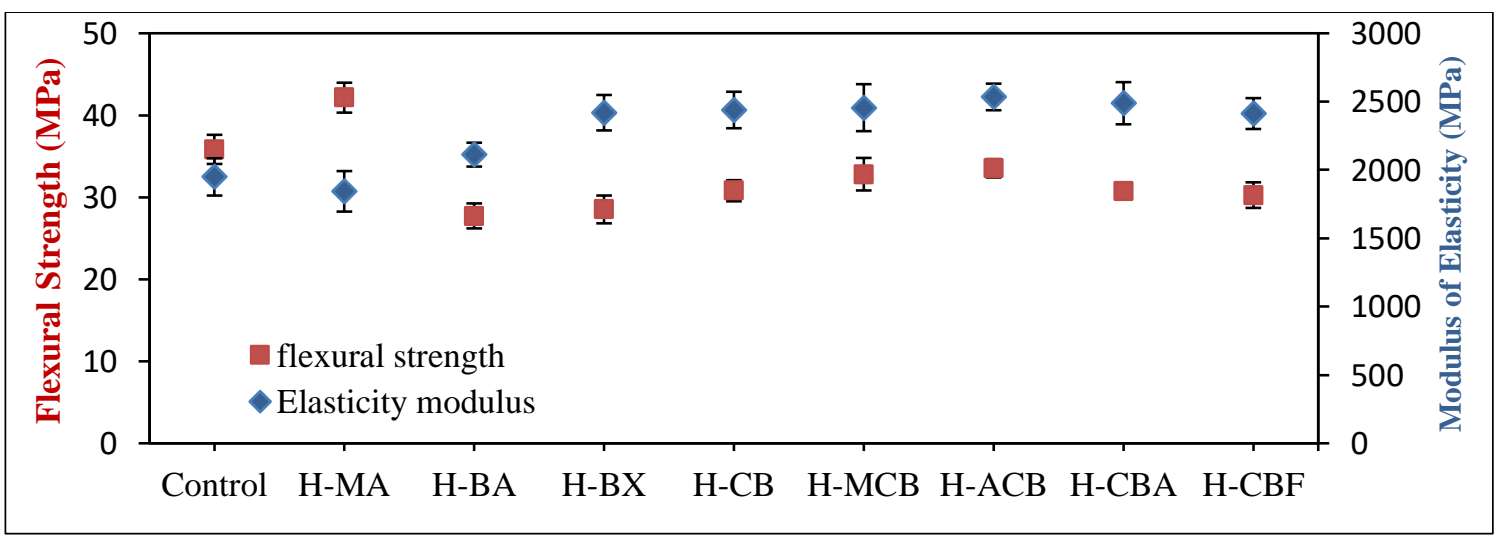

Figure 2. Flexural strength and modulus of elasticity of MDFw filled wood plastic composites

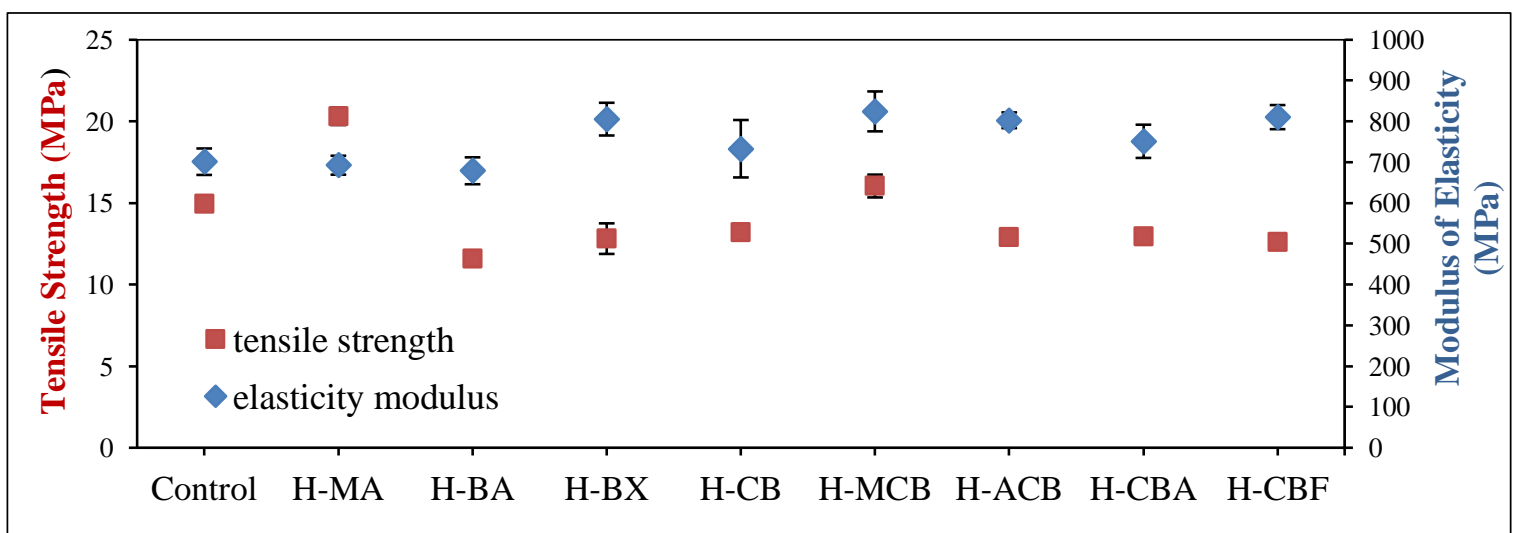

Figure 3. Tensile strength and modulus of elasticity of MDFw filled wood plastic composites 


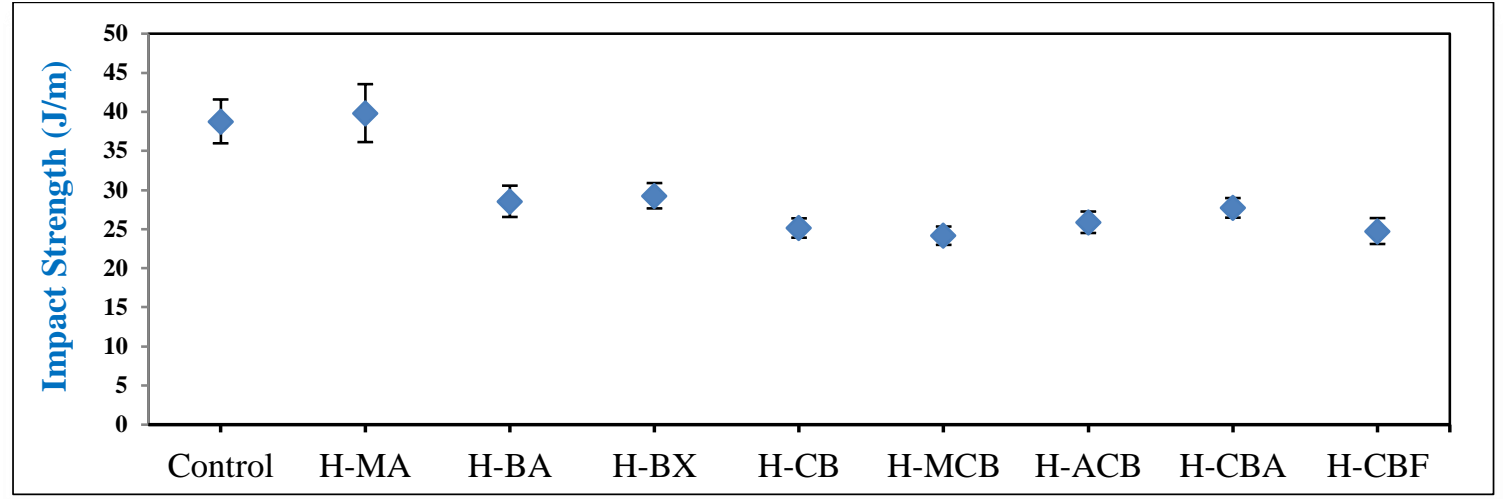

Figure 4. The impact strength of MDFw filled wood plastic composites

Figure 2 shows the FS of samples with MAPE added as compared with the control sample. The FS of H-MA showed the best result and increased by about $17 \%$. However, the FM of H-MA decreased slightly by about $5 \%$. The FS of the group with $3 \%$ MAPE and $12 \%$ zinc borate decreased by $8 \%$ compared with the control group. These compounds block most of the esterification reactions between hydroxyl groups on the lignocellulose fiber surface and anhydride on MAPE. The reaction occurred between the boron compound and MAPE. When the boron compound in the WPCs increased, the adhesion between wood fibers and maleic anhydride decreased. This adhesion reduced the tensile strength (Cavdar, Kalaycioglu, and Mengeloglu, 2016; Kurt and Mengeloglu, 2011; G. F. Wu and Xu, 2014). Composites prepared by mixing zinc borate with other fire retardants were compared for synergic effects. The FS of H-ACB had the best synergistic effect. The FS of the H-ACB decreased by about $6 \%$ according to the control group. But the FS of the $\mathrm{H}-\mathrm{ACB}$ increased by about $9 \%$ according to H-CB. A synergic compound in composites has a negative influence on FS. as previously noted (Kurt and Mengeloglu 2011; Cavdar et al. 2016).

Figure 3 shows the TS of the sample prepared according to Table 4 . The TS and TM of samples prepared by adding only boron compounds were compared with the control. The best TS and TM were obtained in H-CB which only had zinc borate added. The TS of H-CB decreased by $11 \%$, but the TM increased by $4.5 \%$. Similar results were obtained previously (Ayrilmis, 2013;
Ayrilmis et al., 2012).

The TS and TM of samples with MAPE added were compared with the control. The best result was the tensile strength of H-MA. The flexural strength of the H-MA increased by $36 \%$. The TM of H-MA decreased slightly, but when the boron compound was added into the composite with MAPE, the TS of the composite (H-MCB) decreased. The TS of composites with MAPE decrease with the addition of boron compounds (Ayrilmis, 2013; Chiu and Wang, 1998; Hamid and Ahmad, 2011; Sain, Park, Suhara, and Law, 2004). Composites prepared by mixing zinc borate with other fire retardants were compared for synergic effects. The tensile strength and modulus of elasticity of composites with synergic compounds were reduced according to the control group and H-CB (Ayrilmis, Benthien, Thoemen, and White, 2011; Cavdar et al., 2016; Kurt and Mengeloglu, 2011; Stark, White, Mueller, and Osswald, 2010).

\section{Conclusions}

The mechanical, thermal and fire properties of boron compounds and other fire-retardant compounds with synergic effects in WPCs were investigated. The flexural strength and tensile, flexural modulus of the WPC samples with different boron and other fire-retardant compounds were increased. The tensile strength of the composite samples with zinc borate was raised when MAPE was added into the composite sample. The impact strength of composites generally decreased. The adding MAPE into the composites increased with the addition of fire-retardant materials into 
the composites. The burning rate value of $7.33 \mathrm{~mm} / \mathrm{min}$ of the $\mathrm{H}-\mathrm{CB}$ composite was the lowest. The LOI value of $22 \%$ oxygen of the $\mathrm{H}-\mathrm{CB}$ composite was the highest. The WPCs with $12 \%$ zinc borate showed the best fireproofing performance.

\section{Acknowledgments}

This Study was supported by a project (2012-C0370) of the National Boron Research Institute in Turkey.

\section{References}

ASTM D618, (2013). Standard practice for conditioning plastics for testing, ASTM International, West Conshohocken, USA.

ASTM D256, (2007). Standard test method for determining the Izod pendulum impact resistance of plastics, ASTM International, West Conshohocken, USA.

ASTM D638, (2007). Standard test method for tensile properties of plastics, ASTM International, West Conshohocken, USA.

ASTM D790, (2007). Standard test method for flexural properties of unreinforced and reinforced plastics and electrical insulating materials, ASTM International, West Conshohocken. USA.

ASTM D2240, (2010). Standard test method for rubber property - Durometer hardness, ASTM International, West Conshohocken, USA.

ASTM D2863-10, (2000). Standard test method for measuring the minimum oxygen concentration to support candlelike combustion of plastics (oxygen index), ASTM International, West Conshohocken, USA.

ASTM D635, (2014). Standard test method for rate of burning and/or extent and time of burning of plastics in a horizontal position, ASTM International, West Conshohocken, USA.

Ayrilmis, N. (2013). Combined effects of boron and compatibilizer on dimensional stability and mechanical properties of wood/HDPE composites, Composites Part B-Engineering, 44(1), 745-749.

Ayrilmis, N., Akbulut, T., Dundar, T., White, R. H., Mengeloglu, F., Buyuksari, U., Avci, E. (2012). Effect of boron and phosphate compounds on physical, mechanical, and fire properties of wood- polypropylene composites. Construction and Building Materials, 33, 63-69.

Ayrilmis, N., Benthien, J. T., Thoemen, H., and White, R. H. (2011). Properties of Flat-Pressed Wood Plastic Composites Containing Fire Retardants. Journal of Applied Polymer Science, 122(5), 32013210.

Cavdar, A. D., Kalaycioglu, H., and Mengeloglu, F. (2016). Technological properties of thermoplastic composites filled with fire retardant and tea mill waste fiber. Journal of Composite Materials, 50(12), 1627-1634.

Cavdar, A. D., Mengeloglu, F., and Karakus, K. (2015). Effect of boric acid and borax on mechanical, fire and thermal properties of wood flour filled high density polyethylene composites. Measurement, 60, 6-12.

Cavdar, A. D., Mengeloglu, F., Karakus, K., and Tomak, E. D. (2014). Effect of Chemical Modification with Maleic, Propionic, and Succinic Anhydrides on Some Properties of Wood Flour Filled HDPE Composites. Bioresources, 9(4), 6490-6503.

Chai, Y. B., Liu, J. L., and Xing, Z. (2012). Dimensional Stability, Mechanical Properties and Fire Resistance of MUFBoron Treated Wood. Material and Manufacturing Technology Ii, Pts 1 and 2, 341-342, 80-84.

Chiang, W. Y., and Hu, H. C. H. (2001). Phosphate-containing flame-retardant polymers with good compatibility to polypropylene. II. Effect of the flameretardant polymers on polypropylene. Journal of Applied Polymer Science, 82(10), 2399-2403.

Chiu, S. H., and Wang, W. K. (1998). Dynamic flame retardancy of polypropylene filled with ammonium polyphosphate, pentaerythritol and melamine additives. Polymer, 39(10), 1951-1955.

Hamid, M. R. Y., and Ahmad, S. (2011). Effect of Flame Retardants on Wood Plastic Composites-HDPE Based. Composite Science and Technology, Pts 1 and 2, 471-472, 640-645.

Haurie, L., Fernandez, A. I., Velasco, J. I., Chimenos, J. M., Cuesta, J. M., and 
Espiell, F. (2007). Thermal stability and flame retardancy of LDPE/EVA blends filled with synthetic hydromagnesite/aluminium hydroxide/montmorillonite and magnesium hydroxide/aluminium hydroxide/montmorillonite mixtures. Polymer Degradation and Stability, 92(6), 1082-1087.

Karade, S. R. (2010). Cement-bonded composites from lignocellulosic wastes. Construction and Building Materials, 24(8), 1323-1330.

Klyosov, A. A. (2007). Wood-plastic composites: John Wiley and Sons.

Kurt, R., and Mengeloglu, F. (2011). Utilization of boron compounds as synergists with ammonium polyphosphate for flame retardant wood-polymer composites. Turkish Journal of Agriculture and Forestry, 35(2), 155-163.

Kurt, R., Mengeloglu, F., and Meric, H. (2012). The effects of boron compounds synergists with ammonium polyphosphate on mechanical properties and burning rates of wood-HDPE polymer composites. European Journal of Wood and Wood Products, 70(1-3), 177-182.

Leu, S. Y., Yang, T. H., Lo, S. F., and Yang, T. H. (2012). Optimized material composition to improve the physical and mechanical properties of extruded woodplastic composites (WPCs). Construction and Building Materials, 29, 120-127.

Levan, S. L. (1984). Chemistry of Fire Retardancy. Advances in Chemistry Series(207), 531-574.

Matuana, L. M., Balatinecz, J. J., Sodhi, R. N. S., and Park, C. B. (2001). Surface characterization of esterified cellulosic fibers by XPS and FTIR spectroscopy. Wood Science and Technology, 35(3), 191-201.

Mengeloglu, F., and Kabakci, A. (2008). Determination of thermal properties and morphology of eucalyptus wood residue filled high density polyethylene composites. International Journal of Molecular Sciences, 9(2), 107-119.

Nikolaeva, M., and Karki, T. (2016). Influence of fire retardants on the reaction-to-fire properties of coextruded wood-polypropylene composites. Fire and Materials, 40(4), 535-543.

Sain, M., Park, S. H., Suhara, F., and Law, S. (2004). Flame retardant and mechanical properties of natural fibre-PP composites containing magnesium hydroxide. Polymer Degradation and Stability, 83(2), 363-367.

Shen, K. K., Kochesfahani, S., and Jouffret, F. (2008). Zinc borates as multifunctional polymer additives. Polymers for Advanced Technologies, 19(6), 469-474.

Stark, N. M., White, R. H., Mueller, S. A., and Osswald, T. A. (2010). Evaluation of various fire retardants for use in wood flour-polyethylene composites. Polymer Degradation and Stability, 95(9), 19031910.

Wu, G. F., and Xu, M. (2014). Effects of Boron Compounds on the Mechanical and Fire Properties of Wood-chitosan and High-density Polyethylene Composites. Bioresources, 9(3), 4173-4193.

Wu, Z. P., Hu, Y. C., and Shu, W. Y. (2010). Effect of Ultrafine Zinc Borate on the Smoke Suppression and Toxicity Reduction of a Low-Density Polyethylene/Intumescent FlameRetardant System. Journal of Applied Polymer Science, 117(1), 443-449. 